\title{
PENGARUH PERBANDINGAN PASTA KECAMBAH KACANG TUNGGAK (Vigna unguiculata L.) DAN PASTA RUMPUT LAUT (Eucheuma cottonii) TERHADAP KARAKTERISTIK SOSIS ANALOG KACANG TUNGGAK
}

The Effect Comparison of Cowpea Sprout Paste (Vigna unguiculata L.) and Seaweed Paste (Eucheuma cottonii) on The Characteristics of Analogue Cowpea Sausage

\author{
Kadek Wiantini ${ }^{1)}$ (I Gusti Ayu Ekawati ${ }^{2}$, Ni Made Yusa ${ }^{2)}$ \\ 1) Mahasiswa Proram Studi Ilmu dan Teknologi Pangan, Fakultas Teknologi Pertanian, Unud \\ ${ }^{2)}$ Dosen Program Studi Ilmu dan Teknologi Pangan, Fakultas Teknologi Pertanian, Unud \\ Kampus Bukit Jimbaran, Badung-Bali
}

\begin{abstract}
This study aims to determine the effect of cowpea sprout paste and seaweed paste to the characteristics of analogue cowpea sausage, and to know the right ratio of cowpea sprout paste and seaweed paste on the characteristics of analogue cowpea sausage. The experimental design used was completely randomized design with the treatment ratio of cowpea sprout paste and seaweed paste, which consists of 5 levels such as: $90 \%$ cowpea sprout paste : $10 \%$ seaweed paste, $80 \%$ cowpea sprout paste : $20 \%$ seaweed paste, $70 \%$ cowpea sprout paste : $30 \%$ seaweed paste, $60 \%$ cowpea sprout paste : $40 \%$ seaweed paste, and $50 \%$ cowpea sprout paste: $50 \%$ seaweed paste. The treatment was repeated 3 times to obtain 15 units of experiments. The data were analyzed by variance analysis and if the treatment had a significant effect then continued with DMRT (Duncan Multiple Range Test). The results showed that cowpea sprout paste and seaweed paste ratio had a significant effect on water content, protein content, fat content, carbohydrate content, coarse fiber content, elasticity, taste (hedonic), texture (hedonic and scoring) and overall acceptance (hedonic). Comparison of 50\% cowpea sprout paste and $50 \%$ seaweed paste had the best characteristics analogue cowpea sausage, with 69,88\% water content, 2,16\% ash content, 3,77\% protein content, 2,92\% fat content, 21,27\% carbohydrate content, 1,50\% coarse fiber content, elasticity 6,65 N, color and aroma rather liked, texture chewy and liked, taste and overall acceptance liked.
\end{abstract}

Keywords : cowpea sprout, seaweed, analogue sausage

\section{PENDAHULUAN}

Sosis merupakan produk berbahan baku daging yang dihaluskan dengan atau tanpa penambahan bahan pangan lain dan bahan tambahan pangan yang diizinkan dan dimasukkan ke dalam selongsong sosis dengan atau tanpa proses pemasakan (Anon., 2015). Sosis yang sering ditemui di pasaran adalah sosis berbahan dasar daging. Daging banyak mengandung asam lemak jenuh dan kolesterol, yang dapat menyebabkan penyumbatan pembuluh darah atau aterosklerosis jika dikonsumsi secara berlebihan. Selain itu masyarakat golongan vegetarian juga tidak mengkonsumsi sosis daging, oleh karena itu perlu adanya pengganti bahan baku sosis yang berupa daging menjadi bahan baku dari sumber nabati. Penggantian bahan baku sosis yang berupa daging menjadi bahan baku dari sumber nabati dilakukan dengan

\footnotetext{
*Korespondensi Penulis:

Email: kdkwiantini30@gmail.com ${ }^{1)}$
} 
mempertimbangkan sifat-sifat yang dimiliki daging, seperti memiliki kandungan protein yang tinggi dan teksturnya mudah dihancurkan.

Sosis yang menggunakan bahan baku dari sumber nabati biasanya disebut sebagai sosis analog. Menurut Yulistiani dkk., (2013), sosis analog adalah makanan yang dibuat dari bahan bukan daging tetapi mirip dengan sifatsifat daging yang dihaluskan dan diberi bumbu-bumbu lalu dimasukkan dalam selongsong. Banyak alternatif bahan baku sosis pengganti daging yang memiliki kandungan protein tinggi, antara lain adalah gluten, jamur tiram putih, dan berbagai kacang-kacangan seperti kacang tunggak. Kacang tunggak (Vigna unguiculata L.) merupakan salah satu alternatif yang cocok untuk dipilih.

Pemilihan kacang tunggak sebagai bahan baku sosis nabati didasari karena memiliki kandungan protein yang cukup tinggi, dapat dengan mudah ditemukan di pasaran, dan pemanfaatannya pun belum maksimal. Pemanfaatan kacang tunggak hanya sebatas digoreng serta untuk beberapa jenis jajanan maupun sebagai pelengkap suatu resep sayuran (Utomo dan Antarlina, 1998). Selain itu kandungan gizi kacang tunggak tidak kalah dengan daging pada umumnya. Dalam $100 \mathrm{~g}$ kacang tunggak mengandung protein $(22,9 \mathrm{~g})$, air (11 g), lemak (1,4 g), karbohidrat (60,61 g), kalsium (77 mg), fosfor (449 mg), besi $(6,50 \mathrm{mg})$, vitamin A (30 SI), vitamin B1 $(0,92 \mathrm{mg})$, dan vitamin C (2 mg) (Direktorat Gizi, Departemen Kesehatan RI, 1990 dalam Ningsih, 2007).

Kacang tunggak memiliki senyawa antigizi, seperti tripsin inhibitor, asam fitat, pentosan dan tanin yang dapat menurunkan daya cerna nutrisi. Untuk meningkatkan daya cerna nutrisi kacang tunggak maka kacang perlu dikecambahkan terlebih dahulu sehingga senyawa antigizi tersebut dapat dikurangi dan setelah perkecambahan juga terbentuk komponen fitokimia (glokosinolates, antioksidan alami yang berperan untuk kesehatan) (Marto, 2010 dalam Aminah dan Hersoelistyorini, 2012).

Dalam pembuatan sosis, selain bahan baku, bahan lainnya yang juga penting adalah bahan pengisi, bahan pengikat, dan bahan pengenyal. Umumnya tekstur kenyal pada sosis diperoleh dari penggunaan bahan pengisi dan bahan pengenyal. Bahan pengenyal yang digunakan umumnya adalah karagenan, gum arab, glukomana, STPP (Sodium Tripoliphospat), mixphos, dan sodium bikarbonat (Herlina dkk., 2015). Selain bahan pengenyal tersebut ada salah satu bahan pengenyal yang mudah ditemui dan masih dalam bentuk segar yaitu rumput laut. Rumput laut segar memiliki sifat-sifat yang relatif lembut dan baik digunakan sebagai bahan pengenyal karena mengandung karagenan yang mampu membentuk gel. Selain itu rumput laut segar juga masih mengandung zat gizi lainnya seperti serat dan beberapa mineral penting lainnya.

Salah satu rumput laut Indonesia penghasil karagenan yang banyak dibudidayakan adalah Eucheuma cottonii yang memiliki kandungan karagenan 54\% - 73\% (Hambali dkk., 2007). Selain karena kandungan karagenan dan seratnya, teknologi produksi rumput laut Eucheuma cottonii juga relatif murah dan mudah serta penanganan pasca panen relatif mudah dan sederhana. Penambahan rumput laut Eucheuma cottonii dalam pembuatan sosis analog diharapkan dapat meningkatkan kualitas fisikokimia sosis karena kandungan serat dan karagenan di dalamnya.

Berdasarkan hal di atas maka dilakukan penelitian perbandingan pasta kecambah kacang tunggak dan pasta rumput laut sehingga diharapkan mampu menghasilkan sosis analog kacang tunggak sebagai diversifikasi olahan kacang tunggak dan rumput laut, sehingga dapat digunakan sebagai alternatif pangan bagi masyarakat pada umumnya dan khususnya golongan vegetarian. 


\section{METODE PENELITIAN}

\section{Tempat dan Waktu}

Pengolahan sosis analog kacang tunggak dilaksanakan di Laboratorium Pengolahan Pangan, proses analisis dilaksanakan di Laboratorium Analisis Pangan dan Laboratorium Teknik Pasca Panen, dan uji sensoris produk dilaksanakan di Laboratorium Rekayasa dan Pengendalian Mutu Program Studi Ilmu dan Teknologi Pangan Fakultas Teknologi Pertanian Universitas Udayana. Penelitian ini dilaksanakan pada bulan Juli sampai dengan bulan September 2018.

\section{Bahan dan Alat}

Bahan-bahan yang digunakan dalam melaksanakan penelitian ini terdiri dari bahan baku, bahan tambahan, dan bahan kimia. Bahan baku terdiri dari kacang tunggak yang diperoleh dari Pasar Ketapian Denpasar Timur dan rumput laut jenis Eucheuma cottonii yang didapat di Pantai Serangan. Bahan tambahan terdiri dari tapioka, minyak nabati, gula, garam, lada, bawang merah, dan bawang putih yang diperoleh di Pasar Ketapian Denpasar Timur, sedangkan ISP (Isolate Soy Protein) dibeli dari toko online casing sosis di Subang dan selongsong sosis selulosa dibeli dari toko online Fawwaz di Jakarta Timur. Bahan kimia yang digunakan dalam melakukan analisis meliputi $\mathrm{H}_{2} \mathrm{SO}_{4}$, $\mathrm{NaOH}, \mathrm{HCl}$, Heksan, tablet kjeldahl, asam borat, penolpthalin, aquades, kertas saring, benang wool, alkohol, dan kertas whatman 42.

Alat-alat yang digunakan antara lain waskom, panci, sendok, pisau, talenan, kompor, blender (Miyako), oven, aluminium foil, cawan porselin, timbangan analitik (Shimadzu), pemanas listrik, labu kjeldhal (Phyrex), labu takar, desikator, enlenmeyer, soxhlet, tabung soxhlet, muffle (Daihan), pipet tetes, pipet volume (Phyrex), tabung reaksi (Phyrex), gelas beker (Phyrex), pinset, waterbath (Thermology), dan texture analyzer.

\section{Rancangan Penelitian}

Penelitian ini menggunakan rancangan acak lengkap (RAL) dengan perlakuan perbandingan pasta kecambah kacang tunggak dan pasta rumput laut, yaitu: P1 (90:10), P2 (80:20), P3 (70:30), P4 (60:40), P5 (50:50)

Masing-masing perlakuan diulang sebanyak 3 kali sehingga diperoleh 15 unit percobaan. Data yang diperoleh kemudian dianalisis dengan analisis sidik ragam dan dilanjutkan dengan uji Duncan bila perlakuan berpengaruh signifikan (Steel dan Torrie, 1993).

\section{Pelaksanaan Penelitian}

Tahap pelaksanaan penelitian meliputi beberapa tahapan yaitu:

1. Proses Pembuatan Pasta Kecambah Kacang Tunggak

A. Pembuatan Kecambah Kacang Tunggak Kacang tunggak disortasi untuk menghilangkan kotoran, kemudian dicuci agar benar-benar bersih dari kotoran yang masih tertinggal. Direndam dalam air dengan perbandingan kacang tunggak dan air (1:3) selama 8 jam. Kacang tunggak ditiriskan kemudian dikecambahkan selama 12 jam pada suhu kamar (20$25^{\circ} \mathrm{C}$ ) dan $\mathrm{RH}$ mendekati 100\% (Yusniardi dkk., 2010).

B. Pembuatan Pasta Kecambah Kacang Tunggak

Sebelum dibuat pasta, kecambah kacang tunggak diblansing terlebih dahulu pada suhu $\pm 90^{\circ} \mathrm{C}$ selama \pm 5 menit. Kecambah kacang tunggak yang sudah diblansing kemudian diangkat dan ditiriskan, selanjutnya kulit kecambah kacang tunggak dikupas. Kecambah kacang tunggak yang sudah dikupas kulitnya kemudian diblender 
dengan penambahan air $100 \mathrm{ml}$ setiap 250 g kecambah kacang tunggak atau dengan perbandingan $1: 2,5$ (Cahyani, 2011, yang dimodifikasi).

\section{Proses Pembuatan Pasta Rumput Laut}

Jenis rumput laut yang digunakan dalam pembuatan sosis analog ini adalah rumput laut jenis Eucheuma cottonii. Rumput laut disortasi dari kotoran lalu dicuci hingga bersih. Dilakukan perebusan selama 15 menit dengan penambahan air 1:8 kemudian ditiriskan dan didinginkan. Rumput laut lalu dicincang kecil $\pm 0,3 \mathrm{~cm}$, kemudian dilakukan penggilingan dengan blender hingga halus (Yulistiani dkk., 2013, yang dimodifikasi).

\section{Proses Pembuatan Sosis Analog Kacang Tunggak}

Pasta kecambah kacang tunggak dan pasta rumput laut ditimbang sesuai dengan formula lalu dicampur. Tahap selanjutnya yaitu ditambahkan bahan lain seperti tapioka, ISP, minyak nabati, gula, garam, lada, bawang merah, bawang putih, dan diaduk rata sampai adonan sosis kalis. Adonan yang sudah jadi kemudian dimasukkan ke dalam mesin filler atau piping bag. Ujung piping bag dipotong kemudian dimasukkan adonan ke dalam selongsong sosis dengan menekan adonan hingga keluar melalui ujung piping bag. Diusahakan agar tidak ada udara yang terperangkap di adonan dalam selongsong sosis. Ujung selongsong diikat dengan menggunakan karet, selanjutnya sosis direbus selama \pm 10 menit atau sampai sosis mengambang. Sosis yang telah matang lalu diangkat dan direndam dalam air dingin selama \pm 10 menit. Sosis analog dimasukkan dalam kulkas (Zebua dkk., 2014, yang dimodifikasi).

\section{Parameter yang Diamati}

Variabel yang diamati pada penelitian ini meliputi analisis kadar air, kadar abu, kadar protein, kadar lemak, kadar karbohidrat, kadar serat kasar (Sudarmadji dkk., 1997), uji kekenyalan (Kusnadi dkk., 2012) serta uji sensoris hedonik warna, tekstur, aroma, rasa, penerimaan keseluruhan, dan skoring tekstur (Soekarto, 1985).

\section{HASIL DAN PEMBAHASAN}

Hasil analisis kadar air, kadar abu, kadar protein, kadar lemak, kadar karbohidrat dan kadar serat kasar dari pasta kecambah kacang tunggak dan pasta rumput laut dapat dilihat pada Tabel 1.

Hasil analisis kadar air, kadar abu, kadar protein, kadar lemak dan kadar karbohidrat pada sosis analog kacang tunggak dapat dilihat pada Tabel 2 .

Tabel 1.Nilai rata-rata hasil analisis kadar air, kadar abu, kadar protein, kadar lemak, kadar karbohidrat dan kadar serat kasar dari pasta kecambah kacang tunggak dan pasta rumput laut

\begin{tabular}{lcccccc}
\hline \multicolumn{1}{c}{ Bahan } & $\begin{array}{c}\text { Kadar } \\
\text { Air (\%) }\end{array}$ & $\begin{array}{c}\text { Kadar } \\
\text { Abu (\%) }\end{array}$ & $\begin{array}{c}\text { Kadar } \\
\text { Protein (\%) }\end{array}$ & $\begin{array}{c}\text { Kadar } \\
\text { Lemak (\%) }\end{array}$ & $\begin{array}{c}\text { Kadar } \\
\text { Karbohidrat (\%) }\end{array}$ & $\begin{array}{c}\text { Kadar } \\
\text { Serat Kasar (\%) }\end{array}$ \\
\hline Pasta Kecambah & 75,11 & 0,69 & 6,27 & 0,72 & 17,22 & 1,74 \\
Kacang Tunggak & 95,29 & 1,22 & 0,40 & 0,08 & 3,01 & 0,46 \\
Pasta Rumput Laut & 95 & & & & \\
\hline
\end{tabular}


Tabel 2. Nilai rata-rata kadar air, kadar abu, kadar protein, kadar lemak dan kadar karbohidrat pada sosis analog kacang tunggak

\begin{tabular}{cccccc}
\hline Perlakuan & $\begin{array}{c}\text { Kadar Air } \\
(\% \mathrm{bb})\end{array}$ & $\begin{array}{c}\text { Kadar Abu } \\
(\% \mathrm{bb})\end{array}$ & $\begin{array}{c}\text { Kadar Protein } \\
(\% \mathrm{bb})\end{array}$ & $\begin{array}{c}\text { Kadar Lemak } \\
(\% \mathrm{bb})\end{array}$ & $\begin{array}{c}\text { Kadar Karbohidrat } \\
(\% \mathrm{bb})\end{array}$ \\
\hline P1 & $63,53 \pm 0,59 \mathrm{~d}$ & $2,01 \pm 0,07 \mathrm{a}$ & $6,97 \pm 0,16 \mathrm{a}$ & $4,05 \pm 0,19 \mathrm{a}$ & $23,44 \pm 0,84 \mathrm{a}$ \\
P2 & $65,86 \pm 0,41 \mathrm{c}$ & $2,12 \pm 0,03 \mathrm{a}$ & $6,22 \pm 0,21 \mathrm{~b}$ & $3,62 \pm 0,14 \mathrm{~b}$ & $22,19 \pm 0,60 \mathrm{~b}$ \\
P3 & $67,62 \pm 0,24 \mathrm{~b}$ & $2,10 \pm 0,05 \mathrm{a}$ & $5,71 \pm 0,03 \mathrm{c}$ & $3,40 \pm 0,35 \mathrm{bc}$ & $21,17 \pm 0,12 \mathrm{~b}$ \\
P4 & $68,17 \pm 0,61 \mathrm{~b}$ & $2,14 \pm 0,12 \mathrm{a}$ & $5,16 \pm 0,12 \mathrm{~d}$ & $3,03 \pm 0,19 \mathrm{~cd}$ & $21,50 \pm 0,79 \mathrm{~b}$ \\
P5 & $69,88 \pm 0,59 \mathrm{a}$ & $2,16 \pm 0,33 \mathrm{a}$ & $3,77 \pm 0,11 \mathrm{e}$ & $2,92 \pm 0,18 \mathrm{~d}$ & $21,27 \pm 0,79 \mathrm{~b}$ \\
\hline
\end{tabular}

Keterangan : Nilai rata - rata yang diikuti oleh huruf yang berbeda pada kolom yang sama menunjukkan perlakuan berbeda nyata $(\mathrm{P}<0,05)$

\section{Kadar Air}

Hasil sidik ragam menunjukkan bahwa perbandingan pasta kecambah kacang tunggak dengan pasta rumput laut berpengaruh sangat nyata $(\mathrm{P}<0,01)$ terhadap kadar air sosis analog kacang tunggak. Tabel 2 menunjukkan kadar air sosis analog kacang tunggak berkisar antara 63,53\% sampai dengan 69,88\%. Kadar air sosis analog kacang tunggak tertinggi diperoleh dari perlakuan P5 yaitu $69,88 \%$, sedangkan kadar air sosis analog kacang tunggak terendah diperoleh dari perlakuan P1 yaitu 63,53\%.

Peningkatan kadar air terjadi seiring meningkatnya perbandingan pasta rumput laut, hal ini disebabkan karena kadar air pasta rumput laut lebih tinggi yaitu 95,29\% dibandingkan dengan pasta kecambah kacang tunggak yaitu $75,11 \%$. Nilai kadar air sosis menurut SNI 01-3820-2015 maksimal 67\%, perlakuan yang sudah memenuhi SNI adalah P1 dan P2, sedangkan perlakuan yang tidak memenuhi SNI adalah P3, P4, dan P5.

\section{Kadar Abu}

Hasil sidik ragam menunjukkan bahwa perbandingan pasta kecambah kacang tunggak dengan pasta rumput laut berpengaruh tidak nyata $(\mathrm{P}>0,05)$ terhadap kadar abu sosis analog kacang tunggak. Tabel 2 menunjukkan bahwa kadar abu sosis analog kacang tunggak berkisar antara 2,01\% sampai dengan $2,16 \%$. Nilai kadar abu sosis menurut SNI 01-3820-2015 maksimal 3\%, jadi kadar abu sosis analog kacang tunggak semua perlakuan telah memenuhi SNI.

\section{Kadar Protein}

Hasil sidik ragam menunjukkan bahwa perbandingan pasta kecambah kacang tunggak dengan pasta rumput laut berpengaruh sangat nyata $(\mathrm{P}<0,01)$ terhadap kadar protein sosis analog kacang tunggak. Tabel 2 menunjukkan bahwa kadar protein sosis analog kacang tunggak berkisar antara $3,77 \%$ sampai dengan $6,97 \%$. Kadar protein sosis analog kacang tunggak tertinggi diperoleh dari perlakuan P1 yaitu $6,97 \%$ sedangkan kadar protein terendah diperoleh dari perlakuan P5 yaitu 3,77\%.

Peningkatan kadar protein terjadi seiring meningkatnya perbandingan pasta kecambah kacang tunggak. Hal ini disebabkan karena kadar protein pasta kecambah kacang tunggak lebih tinggi yaitu $6,27 \%$ dibandingkan dengan pasta rumput laut $0,40 \%$. Nilai kadar protein sosis menurut SNI 01-3820-2015 minimum $13 \%$, sehingga kadar protein sosis analog kacang tunggak semua perlakuan tidak memenuhi SNI. Nilai kadar protein yang rendah dalam penelitian ini disebabkan karena bahan baku yang digunakan yaitu kecambah kacang tunggak dibuat dalam bentuk pasta, dimana dalam pembuatan pasta tersebut terdapat penambahan air.

\section{Kadar Lemak}

Hasil sidik ragam menunjukkan bahwa perbandingan pasta kecambah kacang 
tunggak dengan pasta rumput laut berpengaruh sangat nyata $(\mathrm{P}<0,01)$ terhadap kadar lemak sosis analog kacang tunggak. Tabel 2 menunjukkan bahwa kadar lemak sosis analog kacang tunggak berkisar atara 2,92\% sampai dengan 4,05\%. Kadar lemak sosis analog kacang tunggak tertinggi diperoleh dari perlakuan P1 yaitu 4,05\% sedangkan kadar lemak terendah diperoleh dari perlakuan P5 yaitu $2,92 \%$ yang tidak berbeda nyata dengan $\mathrm{P} 4$.
Penurunan kadar lemak terjadi seiring menurunnya perbandingan pasta kecambah kacang tunggak. Hal ini disebabkan karena kadar lemak pasta kecambah kacang tunggak lebih tinggi yaitu $0,72 \%$ dibandingkan dengan pasta rumput laut $0,08 \%$. Nilai kadar lemak sosis menurut SNI 01-3820-2015 maksimum $20 \%$, jadi kadar lemak sosis analog kacang tunggak semua perlakuan telah memenuhi SNI.

Tabel 3. Nilai rata-rata kadar serat kasar dan kekenyalan sosis analog kacang tunggak

\begin{tabular}{ccc}
\hline Perlakuan & Serat Kasar $(\% \mathrm{bb})$ & Kekenyalan $(\mathrm{N})$ \\
\hline P1 & $2,07 \pm 0,19 \mathrm{a}$ & $8,46 \pm 0,25 \mathrm{a}$ \\
P2 & $1,98 \pm 0,10 \mathrm{ab}$ & $7,80 \pm 0,12 \mathrm{~b}$ \\
P3 & $1,76 \pm 0,14 \mathrm{bc}$ & $7,62 \pm 0,19 \mathrm{~b}$ \\
P4 & $1,58 \pm 0,14 \mathrm{~cd}$ & $7,61 \pm 0,18 \mathrm{~b}$ \\
P5 & $1,50 \pm 0,11 \mathrm{~d}$ & $6,65 \pm 0,37 \mathrm{c}$ \\
\hline
\end{tabular}

Keterangan : Nilai rata - rata yang diikuti oleh huruf yang berbeda pada kolom yang sama menunjukkan perlakuan berbeda nyata $(\mathrm{P}<0,05)$

\section{Kadar Karbohidrat}

Hasil sidik ragam menunjukkan bahwa perbandingan pasta kecambah kacang tunggak dengan pasta rumput laut berpengaruh nyata $(\mathrm{P}<0,05)$ terhadap kadar karbohidrat sosis analog kacang tunggak. Tabel 2 menunjukkan bahwa kadar karbohidrat sosis analog kacang tunggak berkisar 21,17\% sampai dengan 23,44\%. Kadar karbohidrat sosis analog kacang tunggak tertinggi diperoleh dari perlakuan P1 yaitu 23,44\% sedangkan kadar karbohidrat terendah diperoleh dari perlakuan P3 yaitu $21,17 \%$ serta tidak berbeda nyata dengan perlakuan P2, P4, dan P5.

Semakin berkurang penggunaan pasta kecambah kacang tunggak menyebabkan kadar karbohidrat sosis analog kacang tunggak semakin rendah. Hal ini disebabkan karena kadar karbohidrat pasta kecambah kacang tunggak lebih tinggi 17,22\% dibandingkan dengan pasta rumput laut 3,01\%. Menurut Sugito dan Hayati (2006), kadar karbohidrat yang dihitung secara $B y$ difference dipengaruhi oleh komponen nutrisi lain, semakin rendah komponen nutrisi lain maka kadar karbohidrat akan semakin tinggi. Begitu juga sebaliknya semakin tinggi komponen nutrisi lain maka kadar karbohidrat akan semakin rendah. Komponen nutrisi yang mempengaruhi besarnya kandungan karbohidrat diantaranya adalah kandungan protein, lemak, air, dan abu.

\section{Kadar Serat Kasar}

Hasil sidik ragam menunjukkan bahwa perbandingan pasta kecambah kacang tunggak dengan pasta rumput laut berpengaruh sangat nyata $(\mathrm{P}<0,01)$ terhadap kadar serat kasar sosis analog kacang tunggak. Tabel 3 menunjukkan bahwa kadar serat kasar sosis analog kacang tunggak berkisar 1,50\% sampai dengan 2,07\%. Kadar serat kasar sosis analog kacang tunggak tertinggi diperoleh dari perlakuan P1 yaitu $2,07 \%$ yang tidak berbeda nyata dengan P2, sedangkan kadar lemak terendah diperoleh dari perlakuan P5 yaitu 1,50\% yang tidak berbeda nyata dengan $\mathrm{P} 4$. 
Penurunan kadar serat kasar terjadi seiring menurunnya perbandingan pasta kecambah kacang tunggak. Hal ini disebabkan karena kadar serat kasar pasta kecambah kacang tunggak lebih tinggi yaitu $1,74 \%$ dibandingkan dengan pasta rumput laut $0,46 \%$.

\section{Kekenyalan}

Hasil sidik ragam menunjukkan bahwa perbandingan pasta kecambah kacang tunggak dengan pasta rumput laut berpengaruh sangat nyata $(\mathrm{P}<0,01)$ terhadap kekenyalan sosis analog kacang tunggak. Tabel 3 menunjukkan bahwa nilai force yang menentukan kekenyalan sosis analog kacang tunggak berkisar antara 6,65 $\mathrm{N}$ sampai dengan 8,46 N. Nilai force merupakan suatu tekanan yang diberikan pada suatu produk untuk mengetahui tingkat kekerasan produk tersebut. Menurut Elita (2016) semakin tinggi nilai force yang dihasilkan oleh texture analyzer menunjukkan bahwa produk tersebut mempunyai tekstur yang semakin tidak kenyal. Nilai force tertinggi diperoleh dari perlakuan $\mathrm{P} 1$ yaitu $8,46 \mathrm{~N}$ yang berarti memiliki tingkat kekenyalan terendah, sedangkan nilai force terendah diperoleh dari perlakuan P5 yaitu 6,65 $\mathrm{N}$ yang berarti memiliki tingkat kekenyalan tertinggi. Kekenyalan sosis analog kacang tunggak semakin meningkat seiring meningkatnya perbandingan pasta rumput laut. Hal ini disebabkan karena pada rumput laut terdapat kandungan karagenan yang berfungsi sebagai pengenyal dalam pembuatan olahan makanan.

\section{Evaluasi Sensoris}

Evaluasi sensoris sosis analog dilakukan dengan uji hedonik terhadap warna, aroma, rasa, tekstur dan penerimaan keseluruhan. Uji skoring dilakukan terhadap tekstur sosis analog kacang tunggak. Nilai rata-rata uji hedonik terhadap warna, aroma, rasa, tekstur, dan penerimaan keseluruhan sosis analog kacang tunggak dapat dilihat pada Tabel 4 .
Nilai rata-rata uji skoring terhadap tekstur sosis analog kacang tunggak dapat dilihat pada pada Tabel 5.

\section{Warna}

Hasil sidik ragam menunjukkan bahwa perbandingan pasta kecambah kacang tunggak dengan pasta rumput laut berpengaruh tidak nyata $(\mathrm{P}>0,05)$ terhadap warna (uji hedonik) sosis analog kacang tunggak. Tabel 4 menunjukkan bahwa nilai rata-rata uji hedonik terhadap warna sosis analog kacang tunggak berkisar antara 4,95 (agak suka) sampai dengan 5,55 (suka). Hal ini disebabkan karena bahan baku yang digunakan yaitu pasta rumput laut yang memiliki warna dominan hijau terdapat pada semua perlakuan sehingga tidak mempengaruhi tingkat kesukaan warna.

\section{Aroma}

Hasil sidik ragam menunjukkan bahwa perbandingan pasta kecambah kacang tunggak dengan pasta rumput laut berpengaruh tidak nyata $(\mathrm{P}>0,05)$ terhadap aroma (uji hedonik) sosis analog kacang tunggak. Tabel 4 menunjukkan bahwa nilai rata-rata uji hedonik terhadap aroma sosis analog kacang tunggak berkisar antara 5,05 (agak suka) sampai dengan 5,50 (suka). Hal ini disebabkan karena pada pasta kecambah kacang tunggak dan pasta rumput laut tidak memiliki aroma yang dominan. 
Tabel 4. Nilai rata-rata uji hedonik warna, aroma, rasa, tekstur, dan penerimaan keseluruhan sosis analog kacang tunggak

\begin{tabular}{cccccc}
\hline Perlakuan & Warna & Aroma & Rasa & Tekstur & Penerimaan Keseluruhan \\
\hline P1 & $5,30 \mathrm{a}$ & $5,05 \mathrm{a}$ & $4,30 \mathrm{~b}$ & $4,60 \mathrm{~d}$ & $4,80 \mathrm{~b}$ \\
P2 & $5,55 \mathrm{a}$ & $5,10 \mathrm{a}$ & $4,60 \mathrm{~b}$ & $4,80 \mathrm{~cd}$ & $5,00 \mathrm{~b}$ \\
P3 & $5,40 \mathrm{a}$ & $5,25 \mathrm{a}$ & $5,50 \mathrm{a}$ & $5,25 \mathrm{bc}$ & $5,70 \mathrm{a}$ \\
P4 & $5,15 \mathrm{a}$ & $5,30 \mathrm{a}$ & $5,85 \mathrm{a}$ & $5,75 \mathrm{ab}$ & $5,95 \mathrm{a}$ \\
P5 & $4,95 \mathrm{a}$ & $5,50 \mathrm{a}$ & $6,10 \mathrm{a}$ & $5,90 \mathrm{a}$ & $6,00 \mathrm{a}$ \\
\hline
\end{tabular}

Keterangan: Nilai rata-rata yang diikuti oleh huruf yang berbeda pada kolom yang sama menunjukkan perlakuan berbeda nyata $(\mathrm{P}<0,05)$

Kriteria hedonik: 1 (sangat tidak suka); 2 (tidak suka); 3 (agak tidak suka); 4 (Biasa); 5 (agak suka); 6 (suka); 7 (sangat suka)

Tabel 5. Nilai rata-rata uji skoring tekstur sosis analog kacang tunggak

\begin{tabular}{cc}
\hline Perlakuan & Tekstur \\
\hline P1 & $2,60 \mathrm{~d}$ \\
P2 & $3,10 \mathrm{c}$ \\
P3 & $3,50 \mathrm{bc}$ \\
P4 & $3,95 \mathrm{ab}$ \\
P5 & $4,20 \mathrm{a}$ \\
\hline
\end{tabular}

Keterangan: Nilai rata-rata yang diikuti oleh huruf yang berbeda pada kolom yang sama menunjukkan perlakuan berbeda nyata $(\mathrm{P}<0,05)$

Kriteria skoring: 1 (sangat tidak kenyal); 2 (tidak kenyal); 3 (agak kenyal); 4 (kenyal); 5 (sangat kenyal)

\section{Rasa}

Hasil sidik ragam menunjukkan bahwa perbandingan pasta kecambah kacang tunggak dengan pasta rumput laut berpengaruh sangat nyata $(\mathrm{P}<0,01)$ terhadap rasa (uji hedonik) sosis analog kacang tunggak. Tabel 4 menunjukkan bahwa nilai rata-rata uji hedonik terhadap rasa sosis analog kacang tunggak berkisar antara 4,30 (biasa) sampai dengan 6,10 (suka). Nilai ratarata uji hedonik terhadap rasa sosis analog tertinggi diperoleh dari perlakuan P5 yaitu 6,10 (suka) dan tidak berbeda nyata dengan P3 dan P4, sedangkan nilai terendah diperoleh dari perlakuan P1 yaitu 4,30 (biasa) dan tidak berbeda nyata dengan P2. Perbedaan rasa disebabkan karena konsentrassi pasta rumput laut dapat mempengaruhi rasa sosis analog kacang tunggak yang dihasilkan. Peningkatan perbandingan pasta rumput laut dapat menurunkan rasa kecambah kacang tunggak yang langu.

\section{Tekstur}

Hasil sidik ragam menunjukkan bahwa perbandingan pasta kecambah kacang tunggak dengan pasta rumput laut berpengaruh sangat nyata $(\mathrm{P}<0,01)$ terhadap tekstur (uji hedonik) sosis analog kacang tunggak. Tabel 4 menunjukkan bahwa nilai rata-rata uji hedonik terhadap tekstur sosis analog kacang tunggak berkisar antara 4,60 (agak suka) sampai dengan 5,90 (suka). Nilai rata-rata uji hedonik terhadap tekstur sosis analog kacang tunggak tertinggi diperoleh dari perlakuan P5 yaitu 5,90 (suka) dan tidak berbeda nyata dengan $\mathrm{P} 4$, sedangkan nilai terendah diperoleh dari perlakuan P1 yaitu 4,60 (agak suka) dan tidak berbeda nyata dengan P2.

Hasil sidik ragam menunjukkan bahwa perbandingan pasta kecambah kacang tunggak dengan pasta rumput laut berpengaruh sangat nyata $(\mathrm{P}<0,01)$ terhadap tekstur (uji skoring) sosis analog kacang 
tunggak. Tabel 5 menunjukkan bahwa nilai rata-rata uji skoring terhadap tekstur sosis analog kacang tunggak berkisar antara 2,60 (agak kenyal) sampai dengan 4,20 (kenyal). Nilai rata-rata uji skoring terhadap tekstur sosis analog kacang tunggak tertinggi diperoleh dari perlakuan P5 yaitu 4,20 (kenyal) dan tidak berbeda nyata dengan P4, sedangkan nilai terendah diperoleh dari perlakuan P1 yaitu 2,60 (agak kenyal).

Hasil yang didapat pada uji hedonik dan skoring tekstur sesuai dengan hasil uji kekerasan menggunakan texture analyser. Tekstur kenyal pada sosis analog kacang tunggak dipengaruhi oleh konsentrasi pasta rumput laut, dimana semakin tinggi konsentrasi pasta rumput laut, maka semakin kenyal tekstur sosis analog kacang tunggak yang dihasilkan.

\section{Penerimaan Keseluruhan}

Hasil sidik ragam menunjukkan bahwa perbandingan pasta kecambah kacang tunggak dengan pasta rumput laut berpengaruh sangat nyata $(\mathrm{P}<0,01)$ terhadap penerimaan keseluruhan (uji hedonik) sosis analog kacang tunggak. Tabel 4 menunjukkan bahwa nilai rata-rata uji hedonik terhadap penerimaan keseluruhan sosis analog kacang tunggak berkisar antara 4,80 (agak suka) sampai dengan 6,00 (suka). Nilai rata-rata uji hedonik terhadap tekstur sosis analog kacang tunggak tertinggi diperoleh dari perlakuan P5 yaitu 6,00 (suka) dan tidak berbeda nyata dengan P3 dan P4, sedangkan nilai terendah diperoleh dari perlakuan P1 yaitu 4,80 (agak suka) dan tidak berbeda nyata dengan P2. Penerimaan keseluruhan sosis analog kacang tunggak dipengaruhi oleh beberapa faktor seperti warna, aroma, rasa, dan tekstur.

\section{SIMPULAN DAN SARAN}

\section{Simpulan}

1. Perbandingan pasta kecambah kacang tunggak dengan pasta rumput laut berpengaruh sangat nyata terhadap kadar air, kadar protein, kadar lemak, kadar serat kasar, kekenyalan, rasa (hedonik), tekstur (hedonik dan skoring), penerimaan keseluruhan (hedonik) sosis analog kacang tunggak, dan berpengaruh nyata terhadap kadar karbohidrat sosis analog kacang tunggak. Perbandingan pasta kecambah kacang tunggak dengan pasta rumput laut tidak berpengaruh terhadap kadar abu, warna (hedonik), dan aroma (hedonik) sosis analog kacang tunggak.

2. Perbandingan $50 \%$ pasta kecambah kacang tunggak : $50 \%$ pasta rumput laut $E$. cottonii menghasilkan karakteristik sosis analog kacang tunggak terbaik berdasarkan uji sensoris dengan kriteria kadar air $69,88 \%$, kadar abu 2,16\%, kadar protein $3,77 \%$, kadar lemak 2,92\%, kadar karbohidrat 21,27\%, kadar serat kasar $1,50 \%$, kekenyalan $6,65 \mathrm{~N}$, warna dan aroma agak suka, tekstur kenyal dan suka, rasa dan penerimaan keseluruhan suka.

\section{Saran}

Berdasarkan hasil penelitian ini disarankan untuk menggunakan perbandingan $50 \%$ pasta kecambah kacang tunggak : 50\% pasta rumput laut $E$. cottonii dalam proses pembuatan sosis analog dan perlu dilakukan penelitian untuk meningkatkan kandungan protein dengan sumber protein yang lainnya atau dengan menggunakan kacang-kacangan dalam bentuk tepung.

\section{DAFTAR PUSTAKA}

Aminah, S. dan W. Hersoelistyorini. 2012. Karakteristik Kimia Tepung Kecambah Serealia Dan Kacang-Kacangan Dengan Variasi Blanching. LPPM UNIMUS. Vol :209-217.

Anonimus. 2015. SNI (Standar Nasional Indonesia) 01-3820-2015 tentang Sosis 
Daging. BSN (Badan Standardisasi Nasional), Jakarta.

Cahyani, K. D. 2011. Kajian Kacang Merah (Phaseolus vulgaris) Sebagai Bahan Pengikat dan Pengisi Pada Sosis Ikan Lele. Skripsi. Tidak dipublikasikan. Fakultas Pertanian. Universitas Sebelas Maret, Surakarta.

Elita, Q. I. Y. 2016. Pengaruh Rasio Tapioka dengan Rumput Laut (Glacilaria sp.) Terhadap Karakteristik Sosis Ikan Lemuru. Skripsi. Tidak dipublikasikan. Fakultas Teknologi Pertanian Unud, Bali.

Hambali, E., A. Suryani, dan Wadli. 2007. Membuat Aneka Olahan Rumput Laut. Penebar Swadaya, Jakarta.

Herlina, I. Darmawan, dan A. S. Rusdianto. 2015. Penggunaan tepung glukomanan umbi gembili (Dioscorea esculenta L.) sebagai bahan tambahan makanan pada pengolahan sosis daging ayam. Jurnal Agroteknologi. 09 (02): 134-144.

Kusnadi, D. C V. P., Bintoro, dan A. N. AlBaarri. 2012. Daya Ikat Air, Tingkat Kekenyalan dan Kadar Protein pada Bakso Kombinasi Daging Sapi dan Daging Kelinci. Jurnal Aplikasi Teknologi Pangan. 1 (2) 28-31.

Ningsih, W. 2007. Evaluasi Senyawa Fenolik (Asam Ferulat dan Asam p-Kumarat) pada Biji, Kecambah dan Tempe Kacang Tunggak (Vigna unguiculata). Skripsi. Tidak dipublikasikan. Institut Pertanian Bogor, Bogor.

Soekarto, S.T. 1985. Penilaian Organoleptik Untuk Industri Pangan dan Pertanian. Bharata Karya Aksara, Jakarta.
Steel, R.G.D dan J.H. Torrie. 1993. Prinsip dan Prosedur Statistika Suatu Pendekatan Biometrik. Penerjemah B. Sumantri. PT. Gramedia Pustaka, Jakarta.

Sudarmadji, S., B. Haryono, dan Suhardi. 1997. Prosedur Analisa Untuk Bahan Makanan dan Pertanian. Liberty, Yogyakarta.

Sugito dan A. Hayati. 2006. Penambahan daging ikan gabus (Ophicepallus strianus) dan aplikasi pembekuan pada pembuatan pempek gluten. Jurnal IlmuIlmu Pertanian Indonesia. 14 (1) : 9-20.

Utomo, J. S. dan S. S. Antarlina. 1998. Teknologi Pengolahan dan ProdukProduk Kacang Tunggak. Monograf Balitkabi. No 3:120-138.

Yulistiani, R., U. Sarofa, dan T. Angastuti. 2013. Sistem emulsi sosis sintetis dari gluten dan rumput laut (Eucheuma cottonii). Jurnal Rekapangan. 7 (2) : 151-166.

Yusniardi, E., B. Kanetro, dan A. Slamet. 2010. Pengaruh jumlah lemak terhadap sifat fisik dan kesukaan meat analog protein kecambah kacang tunggak (Vigna unguiculata). Agritech. 30 (3):148-151.

Zebua, E. A., H. Rusmarilin, dan L. N. Limbong. 2014. Pengaruh perbandingan kacang merah dan jamur tiram dengan penambahan tapioka dan tepung talas terhadap mutu sosis. Jurnal Rekayasa Pangan dan Pertanian. 2 (4): 92-101. 